\title{
PSEUDOMONAS AERUGINOSA SIGNIFICANTLY INCREASES EXPRESSION OF RECEPTOR FOR ADVANCED GLYCATION ENDPRODUCTS (RAGE) IN THE SEPTICEMIA SUFFERING PATIENTS
}

\author{
A. Kariminik, F. Hosseini, E. Nasiri \\ Islamic Azad University, Kerman Branch, Kerman, Iran
}

\begin{abstract}
Receptor for Advanced Glycation Endproducts (RAGE) is a cell surface receptor, which recognizes several endogenous and exogenous molecules and subsequently induces expression of several molecules including chemokines. Chemokines are members of the cytokine superfamily and participate in several immune system functions, including cell migration, inflammation, angiogenesis/angiostasis etc. CXC ligand 11 (CXCL11) is an important chemokine which participates in the induction of appropriate immune responses against microbes, including bacteria. The main mechanisms responsible to overcome septicemia are yet to be clarified. Thus, it has been hypothesized that RAGE may participate in induction of CXCL11 in response to the microbial agents. Due to the fact that immune responses play key roles in limitation of infection, it has been proposed that RAGE may inhibit spread of septicemia. Therefore, in this project mRNA levels of RAGE and CXCL11 were explored in the patients suffering from septicemia versus healthy controls. RAGE and CXCL11 expression levels in the 80 subjects, including 40 septicemia patients and 40 healthy controls were explored using Real-Time PCR technique. Accordingly, by using the specific primer against RAGE and CXCL11 in a Rotorgene vehicle the mRNA levels have been determined. The septicemia and the sources of the bacteria in the blood were diagnosed using microbial cultures. The results demonstrated that although mRNA levels for RAGE and CXCL11 did not change in the septicemia patients vs. healthy controls, mRNA levels of RAGE were significantly higher in the patients infected by Pseudomonas aeruginosa compared to those infected by other bacteria, Escherichia coli, Staphylococcus aureus, and Acinetobacter baumannii. RAGE and CXCL11 mRNA levels did not differ among male and female patients. Based on the results it seems that RAGE is a critical receptor against $P$. aeruginosa during septicemia and more investigations, especially on the RAGE down-stream molecules can clarify its main roles against $P$. aeruginosa.
\end{abstract}

Key words: septicemia, RAGE, CXCL11, gene expression.

\section{PSEUDOMONAS AERUGINOSA СУЩЕСТВЕННО УСИЛИВАЕТ ЭКСПРЕССИЮ РЕЦЕПТОРА ДЛЯ КОНЕЧНЫХ ПРОДУКТОВ ГЛИКИРОВАНИЯ (RAGE) У ПАЦИЕНТОВ С СЕПТИЦЕМИЕЙ}

Кариминик А., Носсеини Ф., Насири Э.

Исламский университет Азад, филиал в г. Керман, г. Керман, Иран

Резюме. Рецептор для конечных продуктов гликирования (RAGE) представляет собой поверхностную структуру, распознающую несколько эндогенных и экзогенных молекул и впоследствии индуцирующую экспрессию нескольких молекул, включая хемокины. Хемокины являются представителями суперсемейства цито-

\author{
Адрес для переписки: \\ Кариминик Ашраф \\ 7635131167, Иран, г. Керман, б-р Имама Али, \\ Исламский университет Азад, филиал в г. Керман. \\ Тел.: +983433210043 \\ E-mail: a.kariminik@iauk.ac.ir
}

\author{
Contacts: \\ Ashraf Kariminik \\ 7635131167, Iran, Kerman, Emam Ali blvd, \\ Islamic Azad University, Kerman Branch. \\ Phone: +98343321 0043 . \\ E-mail: a.kariminik@iauk.ac.ir
}

\section{Для цитирования:}

Кариминик А., Носсеини Ф., Насири Э. Pseudomonas aeruginosa

существенно усиливает экспрессию рецептора для конечных

продуктов гликирования (RAGE) у пациентов с септицемией //

Инфекция и иммунитет. 2021. Т. 11, № 5. С. 984-988. doi: 10.15789/2220-

7619-PAS-1253

\section{Citation:}

Kariminik A., Hosseini F., Nasiri E. Pseudomonas aeruginosa significantly increases expression of receptor for advanced glycation endproducts (RAGE) in the septicemia suffering patients // Russian Journal of Infection and Immunity = Infektsiya i immunitet, 2021, vol. 11, no. 5, pp. 984-988. doi: 10.15789/2220-7619-PAS-1253 
кинов и участвуют в процессах миграции клеток, воспаления, в ангиогенезе/ангиостазе и т. д. СХС-лиганд 11 (CXCL11) является важным хемокином, участвующим в индукции антимикробного (в том числе антибактериального) ответа. Основные механизмы, ответственные за излечение от сепсиса, еще предстоит выяснить. Было высказано предположение, что RAGE может участвовать в индукции CXCL11 в ответ на микробные агенты. В связи с тем, что иммунный ответ играет ключевую роль в ограничении инфекции, было предположено, что RAGE может сдерживать септицемию. Поэтому в настоящем проекте были исследованы уровни мPHK RAGE и CXCL11 у пациентов, страдающих септицемией, и проведено их сравнение с аналогичными показателями здоровых людей контрольной группы. Уровни экспрессии RAGE и CXCL11 у 80 субъектов, включая 40 пациентов с сепсисом и 40 здоровых людей из контрольной группы, были исследованы с использованием метода ПЦР в реальном времени. В амплификаторе Rotorgene с использованием специфического праймера против RAGE и CXCL11 были определены уровни мРНК. Септицемию и источники бактерий в крови диагностировали с помощью культурального метода. Результаты показали, что, хотя уровни мPHK RAGE и CXCL11 не изменились у пациентов с сепсисом по сравнению со здоровыми людьми из контрольной группы, уровни мPHK RAGE были значительно выше у пациентов, инфицированных Pseudomonas aeruginosa, по сравнению с пациентами, инфицированными другими бактериями: Escherichia coli, Staphylococcus aureus и Acinetobacter baumannii. Уровни мPHK RAGE и CXCL11 не различались у пациентов мужского и женского пола. На основании полученных результатов можно сделать вывод о том, что при сепсисе присутствие RAGE является критическим для диссеминации P. aeruginosa в организме, и дополнительные исследования, особенно в отношении молекул, получающих сигналы от RAGE, могут прояснить роль этих рецепторов при сесписе, индуцированном $P$. aeruginosa .

Ключевые слова: септицемия, RAGE, CXCL11, экспрессия гена.

\section{Introduction}

Extracellular immune receptors are the main pattern recognition receptors (PRRs) and significantly participate in recognition of pathogens. The molecules induce appropriate immune responses by activation of intracellular pathways and expression of immune related molecules such as chemokines [2, 9]. Receptor for Advanced Glycation Endproducts (RAGE) is a cell surface receptor which play key roles in activation of immune cells to activate by recognition of pathogen associated molecular patterns (PAMPs) and also damage associated molecular patterns (DAMPs) [5, 8]. The receptor induce expression of several immune related molecules, like chemokines via activation of corresponded transcription factors [11]. CXCL11, which is called also as Interferon-gamma-inducible protein 9 (IP-9), plays crucial roles in recruitment of $\mathrm{T}$ lymphocytes to the infected tissues and also activation of the immune cells against the bacteria [3, 4]. On the other hand, it has been documented that septicemia usually observed in the immunocompromised patients [7]. Therefore, it may be hypothesized that the patients suffering from septicemia may be defected in appropriate expression of innate immune receptors such as RAGE and its down-stream molecule, CXCL11. Our previous investigations revealed that melanoma differentiation-associated protein 5 (MDA5) and retinoic acid-inducible gene 1 (RIG-1), two important intracellular receptors, are up-regulated during septicemia [1]. Thus, we have hypothesized that MDA5 and RIG-1 are the important receptors, which participate in the recognition of bacteria during septicemia. However, there were no publications regarding the status of expression of RAGE and CXCL11 in the patients. Therefore, mRNA levels of RAGE and
CXCL11 were explored in the patients suffering from septicemia compared to healthy controls.

Additionally, this project was explore the mRNA levels of RAGE and CXCL11 among male and female patients and also among the patients infected with various bacteria. Additionally, due to the fact that we had explored the mRNA levels of MDA5 and RIG-1 in the patients, another aim of this project was to evaluate the correlation among the expression of MDA5, RIG-1, RAGE and CXCL11 in the infected patients.

\section{Material and methods}

Subjects. This cross-sectional study was carried out on the samples which have prepared in our previous investigations [1]. Accordingly, the sample size (40 patients and 40 controls), including and excluding criteria, place of the sampling (all hospitals of Kerman city, Kerman, Iran), blood culture, mRNA extraction and cDNA synthesizes have been described in details in our previous investigations [1]. The Ethical Committee of Islamic Azad University, Kerman Branch, approved the protocol of the current study. Accordingly, all participants filled out the informed consent form.

Real-time PCR were performed according to our previous study protocol [1], except the primer sequences which were for RAGE:

5'-ATCTTGATTAGCATCCAGG-3' (Forward),

5'-GACCCTGGAAGGAAGCAG-3' (Reverse), and for CXCL11:

5'-ATCTGTGGTTACGGTGGAGA-3' (Forward), 5'-TGTTTGGGGAAAGAAGTGTG-3' (Reverse).

Data analysis and statistical methods. Due to the abnormality data distribution, Mann-Whitney U test, to analysis the differences between the septicemia 

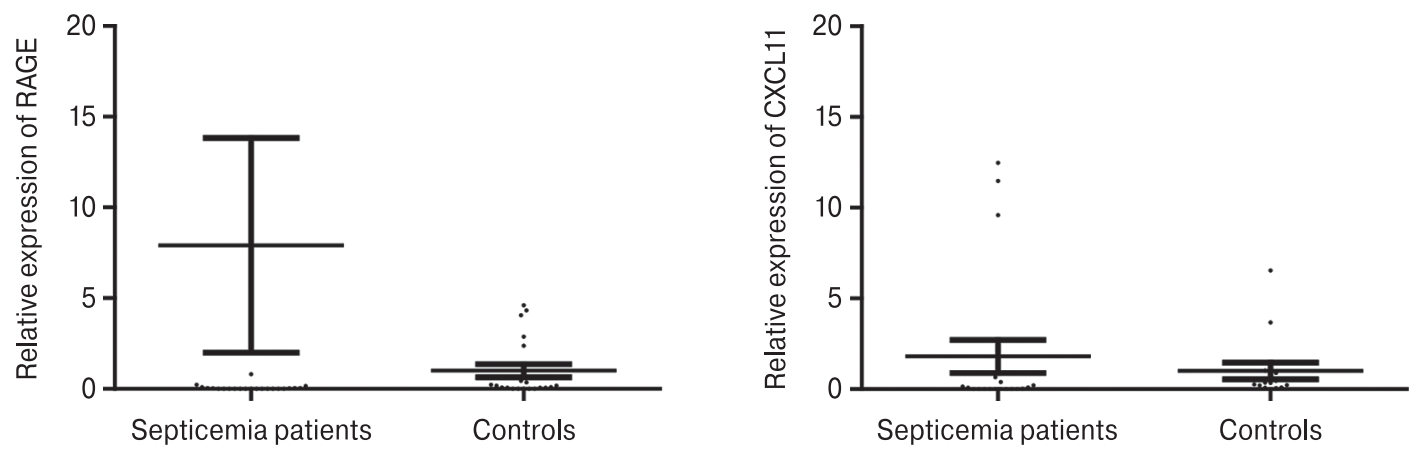

Figure 1. RAGE and CXCL11 expression levels in the septicemia patients and healthy controls

Note. Figure shows mRNA levels of RAGE and CXCL11 did not significantly differ in septicemia patients in comparison to healthy controls.

patients and healthy controls and male versus female cases) and Kruskal-Wallis test, to analysis the differences among the patients infected with various bacteria, under SPSS software version 18 . $\mathrm{P}$ value was considered significant at $<0.05$.

\section{Results}

Identification of septicemia. Due to the fact that the samples which are used in this project were obtained in our previous investigations, the infected patients were as our previous study as follow: 7 Escherichia coli, 10 Staphylococcus aureus, 17 Acinetobacter baumannii and 6 Pseudomonas aeruginosa infected patients.

Expression levels of RAGE and CXCL11. Results demonstrated that RAGE mRNA levels in the peripheral blood immune cells (PBIC) of the septicemia patients were $0.0204(0.0048-0.2180)$ and in the PBIC of healthy controls were 0.1362 (0.0254-1.8975). Statistical analysis demonstrated no significant difference $(\mathrm{p}=0.095)$. CXCL11 mRNA levels in the septicemia patients were $0.0483(0.0033-0.5981)$ and in healthy controls were 0.3489 (0.0935-0.8956). Statistical analysis demonstrated no significant difference $(p=0.057)$. Fig. 1 shows the expression levels of RAGE and CXCL11 in both septicemia patients and healthy controls.

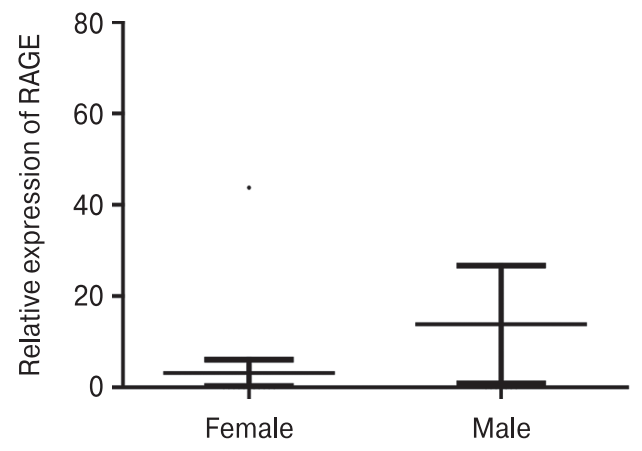

Expression levels of RAGE ( $\mathrm{p}=0.079)$ and CXCL11 ( $p=0.208)$ were also not significantly differ in the female when compared to male septicemia patients (Fig. 2).

Results shows that, although RAGE mRNA levels $(\mathrm{p}=0.020)$ were significantly in the $P$. aeruginosa (23.5920 [1.0118-100.2772]) infected septicemia patients than the patients with E. coli $(0.0204$ [3.0005$0.4805]), S$. aureus (0.0342 [0.0110-0.8573]), A. baumannii (0.0087 [0.0021-0.0302]) infection, the mRNA levels of CXCL11 were not changed among the groups $(\mathrm{p}=0.382$, Fig. 3).

The results also revealed that there were a positive moderate correlation between RAGE and MDA5 mRNA levels in the septicemia patients. However, there were no significant correlations between other variables in the septicemia patients (Table).

\section{Discussion}

The results demonstrated that patients were not expressed RAGE and CXCL11 in different manner when compared to the healthy controls. However, the results revealed that the patients who infected by $P$. aeruginosa had higher mRNA levels of RAGE than the patients who were infected by other bacteria. Therefore, it appears that, although RAGE cannot be considered as important receptor against septice-

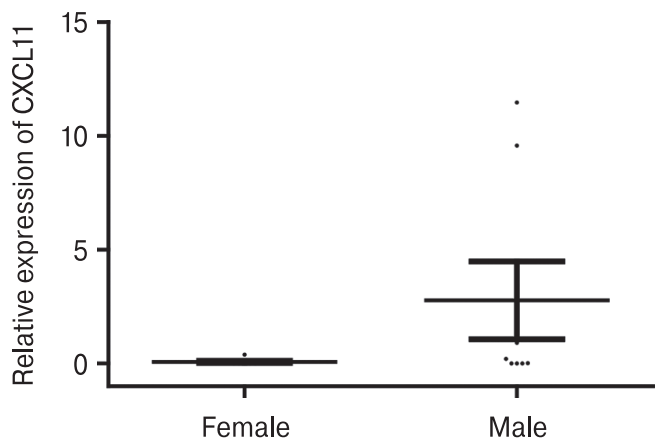

Figure 2. RAGE and CXCL11 expression levels in the female in comparison to male septicemia patients Note. RAGE and CXCL11 mRNA levels did not significantly differ between the female and male septicemia patients. 

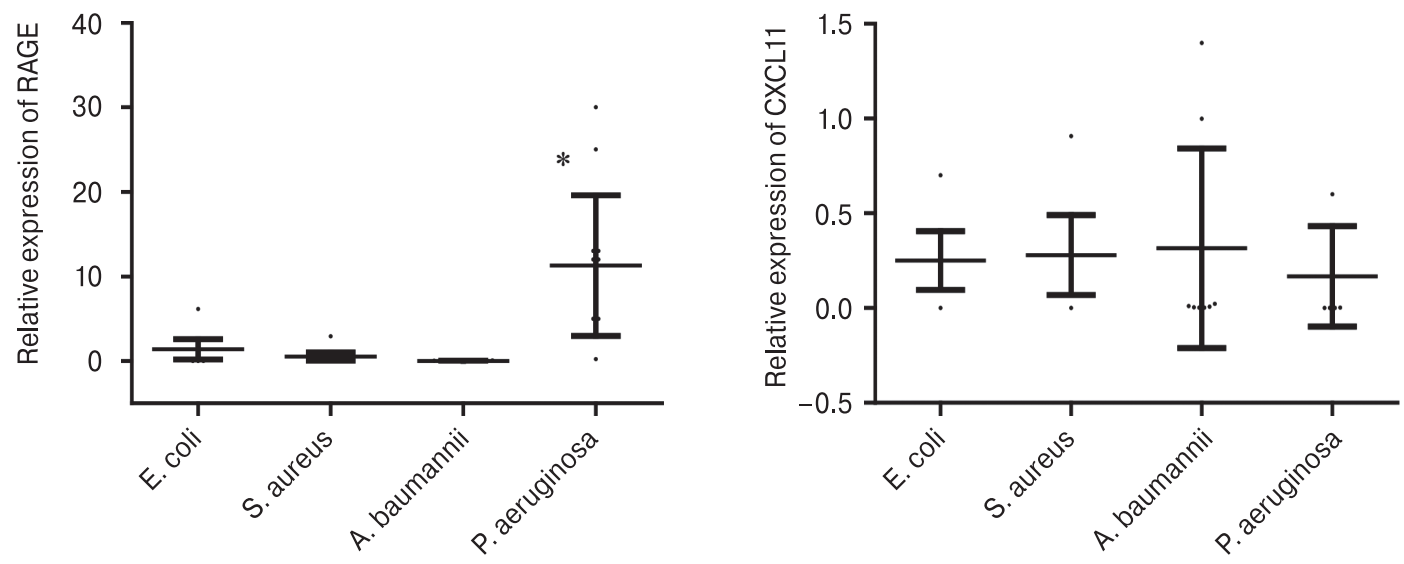

Figure 3. RAGE and CXCL11 expression levels in the septicemia patients

Note. RAGE, but not CXCL11, mRNA levels were significantly increased in Pseudomonas aeruginosa in comparison to Escherichia coli, Staphylococcus aureus and Acinetobacter baumannii infected patients. *P value: 0.02 .

Table. Correlation between age and mRNA levels of RAGE, MDA5, RIG-1 and CXCL11 in the septicemia patients

\begin{tabular}{|c|c|c|c|c|c|c|c|}
\hline & & & RAGE & MDA5 & RIG1 & CXCL11 & Age \\
\hline \multirow{8}{*}{ Spearman's rho } & \multirow{2}{*}{ RAGE } & Correlation Coefficient & 1.000 & $0.402^{\star}$ & 0.052 & -0.006 & -0.046 \\
\hline & & $P$ value & & 0.042 & 0.809 & 0.983 & 0.818 \\
\hline & \multirow{2}{*}{ MDA5 } & Correlation Coefficient & $0.402^{*}$ & 1.000 & 0.361 & 0.237 & 0.034 \\
\hline & & P value & 0.042 & & 0.070 & 0.360 & 0.871 \\
\hline & \multirow{2}{*}{ RIG1 } & Correlation Coefficient & 0.052 & 0.361 & 1.000 & -0.233 & -0.030 \\
\hline & & $P$ value & 0.809 & 0.070 & & 0.386 & 0.889 \\
\hline & \multirow{2}{*}{ CXCL11 } & Correlation Coefficient & -0.006 & 0.237 & -0.233 & 1.000 & 0.185 \\
\hline & & $P$ value & 0.983 & 0.360 & 0.386 & & 0.492 \\
\hline
\end{tabular}

Note. Table illustrates that there were a positive moderate correlation between RAGE and MDA5 mRNA levels in the septicemia patients.

mia, it is important molecule to recognize $P$. aeruginosa in the Iranian patients who were suffered from septicemia. Interestingly, the results also confirmed that there is a significant positive correlation between MDA5 and RAGE in infected patients. As mentioned previously, MDA5 is a main intracellular sensor which induces expression of several immune related molecules such as RAGE [12]. Due to the fact that our previous results demonstrated that MDA5 and RIG-1 significantly increased in the septicemia patients [1], hence, it seems that the results confirmed the roles played by MDA5 to increase expression of RAGE. So, it may be hypothesized that RAGE activated immune responses against $P$. aeruginosa in dependent of MDA, but not RIG-1 and CXCL11. It has been documented that septicemia patients up-regulate pro-inflammatory molecules in the nuclear factor- $\kappa \mathrm{B}(\mathrm{NF}-\kappa \mathrm{B})$ dependent manner [6, 13]. $\mathrm{NF}-\kappa \mathrm{B}$ is an important well-known transcription factor which is activated by several intracellular sign- aling pathways, including MDA5 and also RAGE dependent pathways $[8,10]$. Thus, it may be concluded that the septicemia patients who were infected by $P$. aeruginosa expressed RAGE to overcome the bacteria infection in a positive feedback with MDA5 in $\mathrm{NF}-\kappa \mathrm{B}$ dependent

The results also revealed that RAGE and CXCL11 mRNA levels were not changed between male and female patients and also had not correlate with age. Thus, it may be proposed that sex and age are not the critical risk factors for taking place of septicemia.

Finally, due to the results, it seems that the type of bacteria in the septicemia is a critical factor for involvement of RAGE, as an important extracellular receptor, during septicemia.

\section{Acknowledgements}

This project was supported by a grant from the Kerman Branch, Islamic Azad University, Kerman, Iran.

\section{References}

1. Asadpour-Behzadi A., Kariminik A. RIG-1 and MDA5 are the important intracellular sensors against bacteria in septicemia suffering patients. J. App. Biomed., 2018, vol. 16, no. 4, pp. 358-361. doi: 10.1016/j.jab.2018.01.009

2. Bagheri V., Askari A., Arababadi M.K., Kennedy D. Can Toll-Like Receptor (TLR) 2 be considered as a new target for immunotherapy against hepatitis B infection? Hum. Immun., 2014, vol. 75, no. 6, pp. 549-554. doi: 10.1016/j.humimm.2014.02.018 
3. Ball J.A., Vlisidou I., Blunt M.D., Wood W., Ward S.G. Hydrogen peroxide triggers a dual signaling axis to selectively suppress activated human T lymphocyte migration. J. Immunol., 2017, vol. 198, no. 9, pp. 3679-3689. doi: 10.4049/jimmunol.1600868

4. Erdel M., Laich A., Utermann G., Werner E.R., Werner-Felmayer G. The human gene encoding SCYB9B, a putative novel CXC chemokine, maps to human chromosome 4q21 like the closely related genes for MIG (SCYB9) and INP10 (SCYB10). Cytogenet. Cell Genet., 1998, vol. 81, no. 3-4, pp. 271-272. doi: 10.1159/000015043

5. Franklin T.C., Wohleb E.S., Zhang Y., Fogaca M., Hare B., Duman R.S. Persistent increase in microglial RAGE contributes to chronic stress-induced priming of depressive-like behavior. Biol. Psychiatry, 2018, vol. 83, no. 1, pp. 50-60. doi: 10.1016/j.biopsych.2017.06.034

6. Gao F., Yang Y.Z., Feng X.Y., Fan T.T., Jiang L., Guo R., Liu Q. Interleukin-27 is elevated in sepsis-induced myocardial dysfunction and mediates inflammation. Cytokine, 2016, vol. 88, pp. 1-11. doi: 10.1016/j.cyto.2016.08.006

7. Kalil A.C., Opal S.M. Sepsis in the severely immunocompromised patient. Curr. Infect. Dis. Rep., 2015, vol. 17 , no. 6: 487. doi: 10.1007/s11908-015-0487-4

8. Kang J.H., Hwang S.M., Chung I.Y. S100A8, S100A9 and S100A12 activate airway epithelial cells to produce MUC5AC via extracellular signal-regulated kinase and nuclear factor-kappaB pathways. Immunology, 2015, vol. 144, no. 1, pp. 79-90. doi: 10.1111/ imm. 12352

9. Karimi-Googheri M., Arababadi M.K. TLR3 plays significant roles against hepatitis B virus. Mol. Biol. Rep., 2014, vol. 41, no. 5, pp. 3279-3286. doi: 10.1007/s11033-014-3190-x

10. Matsukura S., Kokubu F., Kurokawa M., Kawaguchi M., Ieki K., Kuga H., Odaka M., Suzuki S., Watanabe S., Homma T., Takeuchi H., Nohtomi K., Adachi M. Role of RIG-I, MDA-5, and PKR on the expression of inflammatory chemokines induced by synthetic dsRNA in airway epithelial cells. Int. Arch. Allergy Immunol., 2007, vol. 143, no. 1, pp. 80-83. doi: 10.1159/000101411

11. Panezai J., Ghaffar A., Altamash M., Sundqvist K.G., Engstrom P.E., Larsson A. Correlation of serum cytokines, chemokines, growth factors and enzymes with periodontal disease parameters. PLoS One, 2017, vol. 12, no. 11: e0188945. doi: 10.1371/journal. pone. 0188945

12. Schnurr M., Duewell P. Induction of immunogenic cell death by targeting RIG-I-like helicases in pancreatic cancer. Oncoimmunology, 2014, vol. 3, no. 9: e955687. doi: 10.4161/21624011.2014.955687

13. Selvaraj V., Manne N.D., Arvapalli R., Rice K.M., Nandyala G., Fankenhanel E., Blough E.R. Effect of cerium oxide nanoparticles on sepsis induced mortality and NF-kappaB signaling in cultured macrophages. Nanomedicine (Lond.), 2015, vol. 10, no. 8, pp. 1275-1288. doi: 10.2217/nnm.14.205

\section{Авторы: \\ Кариминик А., к.н., кафедра микробиологии, Исламский университет Азад, филиал в г. Керман, г. Керман, Иран; Хоссейни Ф., магистр, кафедра микробиологии, Исламский университет Азад, филиал в г. Керман, г. Керман, Иран; Назири Э., магистр, кафедра микробиологии, Исламский университет Азад, филиал в г. Керман, г. Керман, Иран.}

\author{
Authors: \\ Kariminik A., PhD, Department of Microbiology, Kerman Branch, \\ Islamic Azad University, Kerman, Iran; \\ Hosseini F., MSc, Department of Microbiology, Kerman Branch, \\ Islamic Azad University, Kerman, Iran; \\ Nasiri E., MSc, Department of Microbiology, Kerman Branch, \\ Islamic Azad University, Kerman, Iran.
}

